\title{
JUURNAL.RU
}

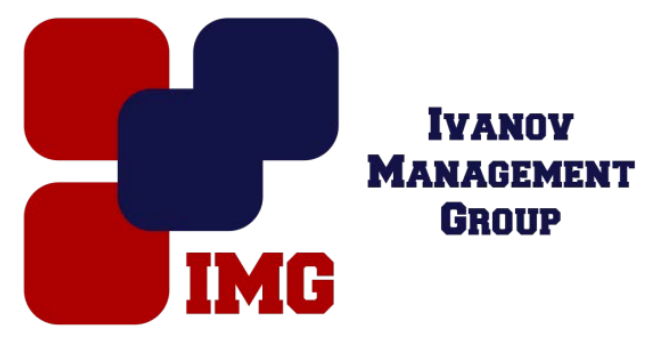

Иудин М.М.

Северо-Восточный федеральный университет имени М.К. Аммосова Якутск, Россия

doi: 10.18411/lj-30-04-2017-2-17

idsp 000001:lj-30-04-2017-2-17

\section{Влияние напряженного состояния на оценку параметров буровзрывных работ}

\begin{abstract}
Аннотация
В геомеханической модели оценки параметров буровзрывных работ при проведении горно-разведочной выработки параметры буровзрывных работ должны рассчитываться с учетом взаимодействия неоднородного поля напряженного состояния массива и энергии взрывчатых веществ при рациональной модели разрушения горных пород.

Ключевые слова: напряженное состояние, геомеханические процессы, горно-разведочная выработка.

Проблема оценки параметров буровзрывных работ при проведении горноразведочных выработок включает в себя разработку теорию расчета параметров буровзрывных работ (БВР), которая максимально учитывала бы влияние горногеологических условий (ГГУ), что позволит варьировать параметры БВР в широком диапазоне.

Из всех элементов горно-геологических условий наибольшее влияние оказывают на параметры буровзрывных работ геомеханические условия, формирующиеся в массиве горных пород вокруг выработки. В составе геомеханических условий выделим физико-механические свойства горных пород, развитие напряженно-деформированного состояния массива горных пород вокруг выработки и процесс разрушения горных пород. Процесс разрушения горных пород при проведении выработки происходит в совокупности от многих факторов геомеханических условий, в том числе и от
\end{abstract}


энергии взрыва в шпуре, что должно быть отражено в методике расчета параметров БВР.

Естественное напряженное состояние массива горных пород определяется геомеханическими условиями, которые можно разделить на две группы: действующие постоянно (гравитационное поле Земли, механические свойства и структурно-механические особенности горных пород, рельеф земной поверхности), и проявляющие временно (тектонические, гидродинамические и другие процессы) [1, 2, 3].

Многолетнемерзлый массив горных пород кроме вышеперечисленных условий формирует и термомеханическое состояние вокруг горно-разведочной выработки. Геомеханические и тепловые процессы в массиве горных пород взаимодействуют и влияют друг на друга, причем эти процессы протекают в динамике проведения и эксплуатации выработки.

При проведении горно-разведочной выработки происходит перераспределение напряженно-деформированного состояния массива горных пород, что формирует неоднородное напряженное состояние на забое выработки. Бурение шпуров вторично изменяет напряженное состояние горных пород вокруг шпура и в целом вокруг забоя выработки. Кроме того, происходит изменение физико-механических свойств горных пород вокруг забоя выработки [1-4]. Эти факторы существенно изменяет напряженное состояние приконтурных слоев массива горных пород. Тогда, разрушение горных пород кроме действия взрыва ВВ в шпуре будет зависеть от уровня и характера действия напряженного состояния массива вокруг забоя горно-разведочной выработки. Поэтому, накладывая ударные волны от энергии взрыва на неоднородное напряженное состояние в районе забоя выработки можно определить общее количество и глубину шпуров, От характера разрушения горных пород рассчитать удельный расход ВВ в шпуре.

Следовательно, от правильного выбора параметров буровзрывных работ с учетом вышесказанных предложений показатели проведения горно-разведочной выработки будут оптимальными и обеспечат соответствие формы и площади поперечного сечения выработки проектным характеристикам. 
1. Иудин М.М. Напряженное состояние массива многолетнемерзлых горных пород // Отечественная геология - 2011. - №6. - С.72-76.

2. Иудин М.М. Напряженное состояние массива горных пород с учетом зоны протаивания и пластических деформаций // Разведка и охрана недр. - 2013. - №12. C.54-56.

3. Иудин М.М. Прогноз напряженного состояния массива мерзлых горных пород вокруг горно-разведочной выработки с учетом пластических деформаций // Разведка и охрана недр. - 2015. - №11. - С.34 - 35.

4. Яковлев А.В., Рождественский В.Н., Пьянзин С.Р. Влияние структурных и физикомеханических свойств пород на параметры буровзрывных работ // Известия вузов. Горный журнал, 2013, №5. - С.75-79. 